\title{
Çelik lifsiz ve lifli ultra yüksek performanslı betonda çimento yerine farklı oranlarda cam tozu ve/veya yüksek firın cürufunun ikamesi
}

\author{
Niyazi BIÇAKÇIOĞLU' ${ }^{1}$, Umut HASGÜL ${ }^{1, *}$ \\ ${ }^{1}$ Balıkesir Üniversitesi, Mühendislik Fakültesi, Inşaat Mühendisliği Bölümü, 10145, Balıkesir, Türkiye \\ Geliş Tarihi (Received Date): 04.11.2021 \\ Kabul Tarihi (Accepted Date): 04.12.2021
}

$\ddot{O} \mathbf{z}$

Bu çalışmada, çelik lifsiz ve lifli Ultra Yüksek Performanslı Beton (UYPB) karışımlarında çimento yerine farklı oranlarda Cam Tozu (CT) velveya Yüksek Fırın Cürufu (YFC) ikamelerinin beton basınç dayanımı üzerindeki etkileri parametrik olarak araştırılmıştır. Bunun için, toplam bağlayıcı miktarının $1000 \mathrm{~kg} / \mathrm{m}^{3}$ olduğu beton karışımı için katkısız kontrol karışımı ile çimento yerine ă̆ırlıkça \%12.5 ve \%25 oranlarında CT velveya YFC'nun ikame edildiği tekli ve ikili bağlayıcı sistemine sahip 16 grup UYPB numunesi üretilmiştir. Bununla birlikte, hacimsel olarak\%1.0 oranında düz çelik liflerin eklendiği aynı sayıda test numunesi daha hazırlanmıştır. 7, 14, 28, 56 ve 90 günlük basınç testleri sonucunda CT ve YFC'nun băgımsız ve birlikte kullanımlarına ilişkin basınç dayanımları kontrol numunesi referans alınarak değerlendirilmiştir. Elde edilen sonuçlar, UYPB'da ă̆ırlıkça \%25'e kadar CT veya $Y F C$ ikamesi ile hedeflenen basınç dayanımlarına ulaşılabileceğini göstermiştir. CT ve YFC'nun ikili kullanımlarıyla basınç dayanımlarının olumsuz etkilendiği ve katkı oranı arttıkça dayanımların hızla azaldığ belirlenmiştir. Beton karışımında daha yüksek oranda katkı kullanılmasıyla çelik liflerin basınç dayanımı üzerindeki etkisi daha önem kazanmıştır.

Anahtar kelimeler: Beton basınç dayanımı, cam tozu, yüksek firın cürufu, çelik lif.

\footnotetext{
Niyazi BIÇAKÇIOĞLU, niyazi_bicakcioglu@hotmail.com, http://orcid.org/0000-0001-8424-080X

*Umut HASGÜL, hasgul@ balikesir.edu.tr, http://orcid.org/0000-0002-9358-3369
} 


\title{
Substitution of different amounts of glass powder and/or ground granulated blast furnace slag in place of cement on ultra-high performance concrete with and without steel fiber
}

\begin{abstract}
In the presented study, the effects of Glass Powder (GP) and/or Ground Granulated Blast Furnace Slag (GGBFS) substitutions in different proportions in place of cement in Ultra High Performance Concrete (UHPC) mixtures with and without steel fiber were parametrically investigated by the compressive strength. In this context, the total of 16 group UHPC specimens consisting of single and dual-uses of GP and GGBFS of $12.5 \%$ and $25 \%$ by weight in place of the cement as well as additive-free control mixture were produced for the concrete mixture where the total amount of binder is $1000 \mathrm{~kg} / \mathrm{m}^{3}$. However, same number of the test specimens were also prepared by inclusion of straight steel fibers of 1.0 vol\%. Based on uniaxial compression tests conducted at the concrete ages of 7, 14, 28, 56 and 90 days, the results with regard to independent and combined uses of GP and GGBFS were discussed by referencing the control mixture. The parametric investigations indicated that the target compressive strengths of UHPC can be obtained with the partial substitution of GP or GGBFS up to $25 \%$ by weight. Not only the compressive strengths were negatively affected by the dual-uses of GP and GGBFS, but also high amount of additive materials led to rapidly strength losses. The effect of steel fibers on the compressive strength became more important with the additive use in higher proportions.
\end{abstract}

Keywords: Concrete compressive strength, glass powder, ground granulated blast furnace slag, steel fiber.

\section{Giriş}

Ultra Yüksek Performanslı Beton (UYPB), çok yüksek basınç dayanımı, ilk çatlak sonrası önemli çekme davranışı, şekildeğiştirme kapasitesi, yüksek durabilite gibi sağladığ 1 pek çok avantaj sayesinde beton teknolojisinin en önemli ürünlerinden biri haline gelmiştir. UYPB, geleneksel normal dayanımlı betonun pek çok eksikliğini (dayanım, süneklik, durabilite, akıcılık, vb.) gidermek amacıyla, alternatif bir güçlü ürün olarak uygulamada yer almaya başlamıştır [1-6]. Günümüzde yüksek binalara, büyük açıklıklı ve özel yapı türlerine olan gereksinimlerin artması, beraberinde çok daha yüksek dayanımlı betonlara olan talebi de artırmaktadır. Özellikle çelik lif içeren UYPB'un yüksek basınç dayanımı ve şekildeğiştirme kapasitesi sayesinde geleneksel ve ön üretimli betonarme elemanlara göre daha estetik ve daha narin kesitli elemanlar üretilebilmektedir. Bunun sonucu olarak, farklı yapısal uygulamalarda (endüstriyel yapılar, köprüler, viyadükler, köprü ayakları, vb.) ve ayrıca yapıların onarım ve güçlendirilmesi ile ağır yüklere maruz endüstriyel zemin döşemelerinde UYPB kullanımı yaygınlaşmıştır [7-10].

Tipik bir UYPB karışımı, çimento, silis dumanı, ince agrega, su ve akışkanlaştırıcı katkdan oluşmaktadır. UYPB'da çok yüksek düzeylerde mekanik özellikler elde etmek amacıyla kullanılan çimento miktarı normal dayanımlı betonlara göre oldukça yüksektir. 
Ancak, su/çimento oranının düşük olması betonun işlenebilirliğini azaltan önemli bir faktördür. Bu bağlamda, karışımın daha akıcı ve homojene yakın bir karaktere sahip olması amacıyla akışkanlaştırıcı ve hava sürükleyici vb. katkılar kullanılmaktadır. UYPB karışımında çimento ve/veya silis dumanı (SD) yerine cam tozu (CT), yüksek firın cürufu (YFC), uçucu kül (UK), zeolit gibi katkı maddeleri kısmi olarak ikame edilebilmektedir. Çimentoya göre çok daha ince tanecikli olan bu katkı malzemeleri betonun iç-yapısındaki boşlukları doldurmaktadır (Şekil 1). Bununla birlikte, sözkonusu katkılar puzolanik özellikleri sayesinde buhar veya basınç kürlemesi sonucunda kimyasal reaksiyona girerek çimento gibi bağlayıcı özellik kazanmakta ve mekanik özelliklerin iyileştirilmesinde önemli bir rol oynamaktadır. UYPB, tek başına kullanıldığında gevrek bir davranışa sahip olduğundan, uygun oranda çelik veya sentetik lifler eklenmesi ile daha üniform bir karakteristik kazanmakta ve bunun sonucunda, şekildeğiştirme ve tokluk kapasiteleri çok daha üst düzeylere çıkmaktadır.

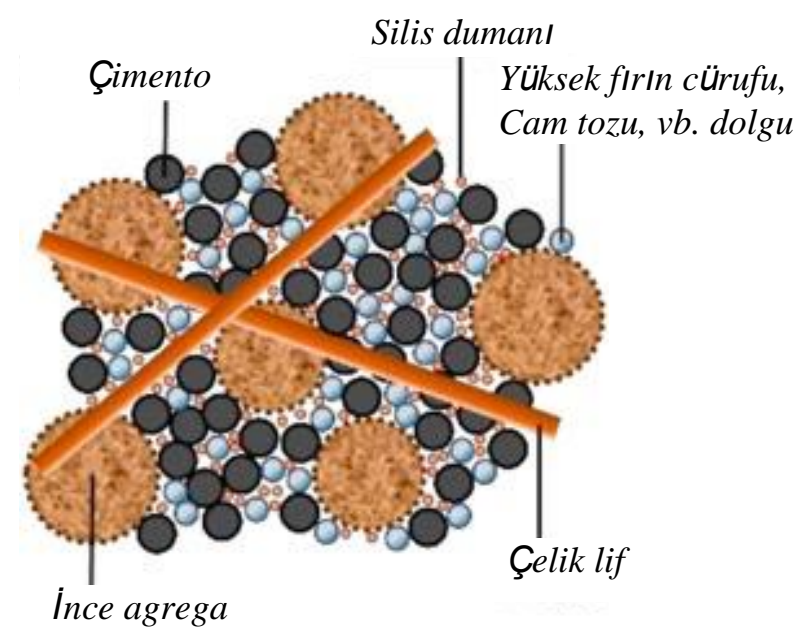

Şekil 1. UYPB'un genel malzeme içeriği [11].

UYPB'nun basınç ve çekme altındaki mekanik özelliklerinin, tokluk ve buna bağlı şekildeğiştirme kapasitesinin iyileştirilmesinde en önemli parametre, karışıma optimum oranda eklenecek çelik liflerdir. Bu amaçla, farklı geometrilerde ve boyutlarda (düz, tek veya çift kancalı, dalgalı, kıvrımlı, vb.) lif tipleri kullanılmaktadır. Üstün mekanik özellikleri ile beraber, sıkı iç-yapı ve liflerin çatlakları sınırlaması sayesinde yeterli oranda çelik lif içeren bu betonlar için Ultra Yüksek Performanslı Lifli Beton (UYPLB) veya Yüksek Performanslı Lif Takviyeli Çimento Kompoziti gibi tanımlar kullanılmaktadır [10,12-14]. UYPLB karışımında kullanılan çelik liflerin hacimsel oranı, geometrisi, narinliği (boy/çap) ve dayanımı betonun mekanik özelliklerin belirlenmesinde oldukça etkin olmakla birlikte, işlenebilirliği azalan olumsuz bir faktördür. UYPLB karışımında tek tip lif kullanımı yerine farklı tiplerde ve oranlarda lifler karma (hybrid) olarak ta kullanılabilmektedir. Karma lif kullanımındaki ana amaç, çatlakların mikro ve makro düzeylerde sınırlı tutulmasıdır. Karma lif içeren UYPB' dan üretilen yapısal elemanlarda, kısa lifler mikro çatlakların oluşumunu ve yayılımını sınırlarken, uzun ve kancalı lifler çatlakları köprüleme özelliği (crack-bridging) sayesinde bölgeleşen çatlakların kontrolünde ve betonun yüksek şekildeğişme kapasitesine ulaşmasında büyük önem arz etmektedir [4,10,14-17]. UYPB karışımında uygun oranda bağlayıcı malzemeler kullanıldığında, genel olarak, standart kür koşulları altında $120 \mathrm{MPa}-130 \mathrm{MPa}$ 'lık bir basınç dayanımı hedeflenmektedir. Bununla birlikte, uygun lif içeriği, düşük su/bağlayıcı oranı ve karışımdaki bağlayıcı malzemelerin 
optimum oranı sonrasında, standart veya özel kür koşulları altında (buhar kürü, basınç kürü, kaynar su kürü, vb.) $150 \mathrm{MPa}$ ve üzeri bir basınç dayanımına sahip olmasının yanısıra, çekme altında pekleşme davranışı göstermesi beklenmektedir [7,13,18-24].

UYPB karışımındaki çimento miktarı geleneksel normal dayanımlı betonlara göre daha fazladır. Son yıllarda yapılan çalışmalarda, çimentonun yüksek maliyeti, çevresel etkiler ve büzülme gibi olumsuz etkileri azaltmak amacıyla CT, YFC ve UK gibi katk1 malzemeleri ikame edilerek beton davranışı farklı parametreler (basınç ve çekme dayanımı, eğilme dayanımı, sünme, iç-yapı, işlenebilirlik, vb.) açısından incelenmiştir $[3,25-34,36]$. Bu bağlamda, CT düşük miktarda puzolanik reaksiyona girerek UYPB karışımında çimento ve diğer bağlayıcılar yerine kısmi olarak kullanılabilmektedir [29]. Beton karışımında kısmi oranda CT ikamesi, çimento üretimi sırasındaki enerji tüketimini ve ayrıca karbon salınımını azaltarak çevre kirliliğine karşı olumlu bir etki oluşturmaktadır [29,33]. Bu şekilde, UYPB'a ait kriterlerin sağlandığı betonun standart kür koşulları altında üretilebileceği görülmüştür [28]. Bununla birlikte, yaygın kullanılan bir yapı malzemesi olan YFC, betonun geçirimliliğini azaltarak daha sıkı bir iç-yapı oluşumuna olanak sağlaması ve betonun mekanik özelliklerinin artırılmasında alternatif bir malzeme olarak kullanılmaktadır. YFC kullanımı, beton üretimine bağlı karbon salınımını azalttığından çevre kirliliği açısından potansiyel pozitif etki de yaratmaktadır [35]. Ayrıca, çimento yerine kısmi olarak YFC'nun kullanılması enerjiden tasarruf sağlamasının yanısıra, ekonomik ve çevresel etkileri azaltan pozitif yönde bir katkı sunmaktadır. Çevre dostu bu tür betonlar için yeşil beton (green concrete) isimlendirmesi de yapılmaktadır [25].

Vaitkevičius vd. [28]'de, UYPB karışımındaki SD ve/veya kuvars unu (KU) yerine farklı oranlarda CT ikame edilerek hedef basınç dayanımına ulaşılabileceği belirtilmiştir. Çalışmada en yüksek basınç dayanımları KU yerine CT'nun kullanıldığı karışımlar için elde edilirken, SD ve KU'nun tamamı yerine CT kullanılması halinde dayanımlarda belirgin bir değişiklik olmamıştır. SD'nın tamamı yerine CT kullanılması halinde ise dayanımların hızla azalan bir eğilimde olduğu görülmüştür. Bu davranışın nedeni, betonun iç-yapısını ve mekanik özelliklerini CT iyileştirmesine karşın, SD kadar iyi bir puzolanik bağlayıcı olmaması olarak açıklanmıştır. Soliman vd. [30]'da, UYPB karışımında SD yerine $\% 30, \% 50$ ve $\% 70$ oranlarında CT ikamesinin basınç dayanımı üzerindeki etkileri incelenmiştir. Çalışmada, \%70SD+\%30CT ve \%50SD+\%50CT karışımlarına ait basınç dayanımlarının daha yüksek olduğu ve CT'nun miktarının artması ile dayanımların azaldığı belirlenmiştir. Yazarların diğer çalışmasında [29], çimento yerine \%20'ye kadar CT ikamesi ile beton basınç dayanımları bir miktar artış göstermiştir. Yazıcı vd. [26] ve Yazıcı [36]' da, UYPB ve Reaktif Pudra Beton (RPB)'da SD miktarı sabit tutularak çimento yerine \%20-\%80 arasında değişen oranlarda YFC veya UK ikameleri sonucunda, \%40'a kadar eklenen katkı malzemelerinin beton basınç dayanımlarını çok az oranda azalttığı, daha yüksek oranlarda ise dayanımlarda ani kayıpların oluştuğu belirlenmiştir.

Yalçınkaya ve Yazıcı [31]'de, \%2 oranında çelik lif içeren katkısız UYPLB karışımı ile çimento yerine $\% 50$ oranında YFC ve \%30 oranında UK'ün ikame edildiği üç karışım için standart kür koşullarında basınç dayanımlarında belirgin bir değişim olmamasına karşın, otoklav kürü sonucunda dayanımların azalım eğiliminde olduğu belirlenmiştir. Dayanımlardaki azalmalara karşın, 150MPa'lık hedef basınç dayanımına ulaşılmıştır. Yavas vd. [14]'de, tek tip çelif liflerin kullanıldığı mono karışımlar ile liflerin karma olarak kullanıldığı UYPLB'un eğilme davranışının yanısıra, basınç ve çekme 
dayanımları araştırılmıştır. Hacimce \%1, \%1.5 ve \%2'lik oranlarda eklenen liflerin beton basınç dayanımlarını \%27-\%51 arasında değişen oranlarda artırdığı belirlenmiştir. Wu vd., [37]'de, farklı geometrilerde çelik lif içeren UYPLB karışımlarında, lif miktarı ve beton yaşı arttıkça basınç dayanımlarının artış eğiliminde olduğu belirlenmiştir. Bununla birlikte, basınç dayanımı bakımından düz liflere göre kancalı ve kıvrımlı liflerin daha etkin olduğu görülmüştür. Birol vd. [38]'de, farklı oranlarda SD ve YFC'nun gözönüne alındığı toplam 24 adet lifsiz UYPB karışım arasında basınç dayanımı bakımından en iyi performans gösteren karışım üzerinde, farklı lif içeriklerinin basınç ve eğilme dayanımına etkileri araştırılmıştır. Kullanılan lif tipinden bağımsız olarak, çelik liflerin 28 günlük basınç dayanımını artırdığı belirtilmiştir. Arel [39]'da, UYPLB'da kullanılan lif uzunluğunun artması ile erken ve ilerleyen beton yaşlarındaki basınç dayanımlarının arttığ 1 görülmüştür. Bununla birlikte, 56 ve 90 günlük dayanımların birbirlerine çok yakın olduğu belirlenmiştir. Smarzewski [40]'da, UYPB'da düz ve kancalı çelik lif kullanımlarının sentetik liflere kıyasla daha iyi performans gösterdiği belirlenmiştir.

Bir seri deneysel sonuçların sunulduğu bu çalışmada, çelik lifsiz ve lifli UYPB karışımlarında çimento yerine farklı oranlarda CT ve/veya YFC ikamelerinin beton basınç dayanımı üzerindeki etkileri parametrik olarak araştırılmıştır. Bu amaçla, toplam bağlayıcı miktarının $1000 \mathrm{~kg} / \mathrm{m}^{3}$ olduğu katkısız UYPB karışımı tasarlanmıştır. Deneysel incelemeler çerçevesinde, katkısız kontrol karışımı ile çimento yerine ağırlıkça \%12.5 ve \%25 oranlarında CT ve YFC'nun bağımsız ve beraber ikame edilmesi ile tekli ve ikili bağlayıcı sistemine sahip toplam 16 adet UYPB karışımı hazırlanmıştır. Bununla birlikte, hacimsel olarak \%1 oranında düz-kısa çelik liflerin eklendiği aynı sayıda test numuneleri üretilmiştir. Çelik lifsiz / lifli beton karışımları için üçer adet hazırlanan toplam 480 adet küp numunenin 7, 14, 28, 56 ve 90 günlük basınç testleri yapılarak ortalama dayanımlar elde edilmiştir. \%12.5-\%50 arasında farklı oranlarda katkı içeren numunelere ait basınç dayanımları kontrol numunesi referans alınarak değerlendirilmiştir.

\section{Deneysel çalışma}

Deneysel çalışma kapsamında ilk olarak, UYPB içeriğinde Cam Tozu (CT) ve Yüksek Fırın Cürufu'nun (YFC) farklı oranlarda bağımsız ve birlikte ikame edilmesi hallerini içeren toplam 16 adet lifsiz UYPB karışımı hazırlanmıştır. Buna ilaveten, lifsiz beton karışımlarına hacimsel olarak \%1.0 oranında düz çelik lifler eklenerek aynı sayıda UYPLB karışımları hazırlanmıştır [41]. İki farklı bağlayıcı miktarı için standart kür koşulları altında üçer adet hazırlanan test numunelerinin 7, 14, 28, 56 ve 90 günlük beton basınç dayanımları belirlenmiştir.

\subsection{Malzeme özellikleri ve bileșenleri}

UYPB'un tasarımında 28 günlük basınç dayanımlarının çelik lifsiz karışımlarda en az $130 \mathrm{MPa}$, lifli karışımlarda ise $140 \mathrm{MPa}$ olması hedeflenmiştir [5,6,9]. Katkısız beton karışımlarında bağlayıcı bileşen olarak çimento ve silis dumanı, katkılı karışımlarda ise, silis dumanı sabit tutularak \%12.5 - \%50 arasında değişen oranlarda çimento miktarı azaltılarak yerine CT ve/veya YFC ikame edilmiştir [41]. Çelik lifsiz ve lifli betonu oluşturan ana ve katkı malzemelerin genel özellikleri aşağıda özetlenmiştir (Şekil 2). 
- Çimento (Ç): Tüm beton karışımlarında özgül yüzeyi $3500-3700 \mathrm{~cm}^{2} / \mathrm{gr}$ ve tane çapı 3-100 mm olan CEM-I 42.5R sınıfı Portland çimentosu ana bağlayıcı malzeme olarak kullanılmıştır.

- Silis Dumanı (SD): Diğer bir bağlayıcı malzeme olan SD’nın tanecik boyutu, çimentonun yaklaşık \%1'i kadardır. SD, karışımdaki çimento tanelerinin arasına girerek boşlukları doldurmakta ve puzolanik reaksiyona girerek daha sıkı bir iç-yapı ve üstün mekanik özellikler elde edilebilmektedir.

- Cam Tozu (CT): Cam'ın mikro boyutta ögütülmesi ile üretilen bu katkı malzemesi, UYPB'da düşük miktarda kullanıldığında puzolanik reaksiyona girdiğinden, karışımda çimento ve/veya SD yerine kısmi olarak kullanılabilmektedir.

- Yüksek Fırın Cürufu (YFC): Betonun geçirimliliğini azaltarak daha sıkı bir içyapının oluşumuna ve betonun mekanik özelliklerini artırmak amaçlı kullanılan bir katkıdır. Karışımdaki ana bağlayıcı miktarını azaltılmak amacıyla da kullanılmaktadır.

- Ince Agrega (AGR): Beton karışımlarında en büyük tane boyutu $0.8 \mathrm{~mm}$ ve özgül ağırlığ $2.68 \mathrm{~g} / \mathrm{cm}^{3}$ olan yüksek dayanımlı kuvars kullanılmıştır.

- Akışkanlaştırıcı (SA): Karışımların işlenebilirliğini artırmak amacıyla yeni nesil polikarboksilik eter esaslı süper akışkanlaştırıcı katkı kullanılmıştır. SA'nın $20^{\circ} \mathrm{C}$ 'deki yoğunluğu $\approx 1.1 \mathrm{~kg} / \mathrm{lt}, \mathrm{pH}$ değeri $\approx 5-7$, Alkali içeriği $\leq \% 3$ 'dür.

- Çelik Lif (ÇL): UYPLB karışımlarında $0.16 \mathrm{~mm}$ çapında ve $13 \mathrm{~mm}$ uzunluğunda (uzunluk/çap $=81$ ) kısa-düz çelik lifler kullanılmıştır. Hacimsel olarak \%1.0 oranında kullanılan liflerin çekme dayanımı $\approx 2500 \mathrm{MPa}$ dır.

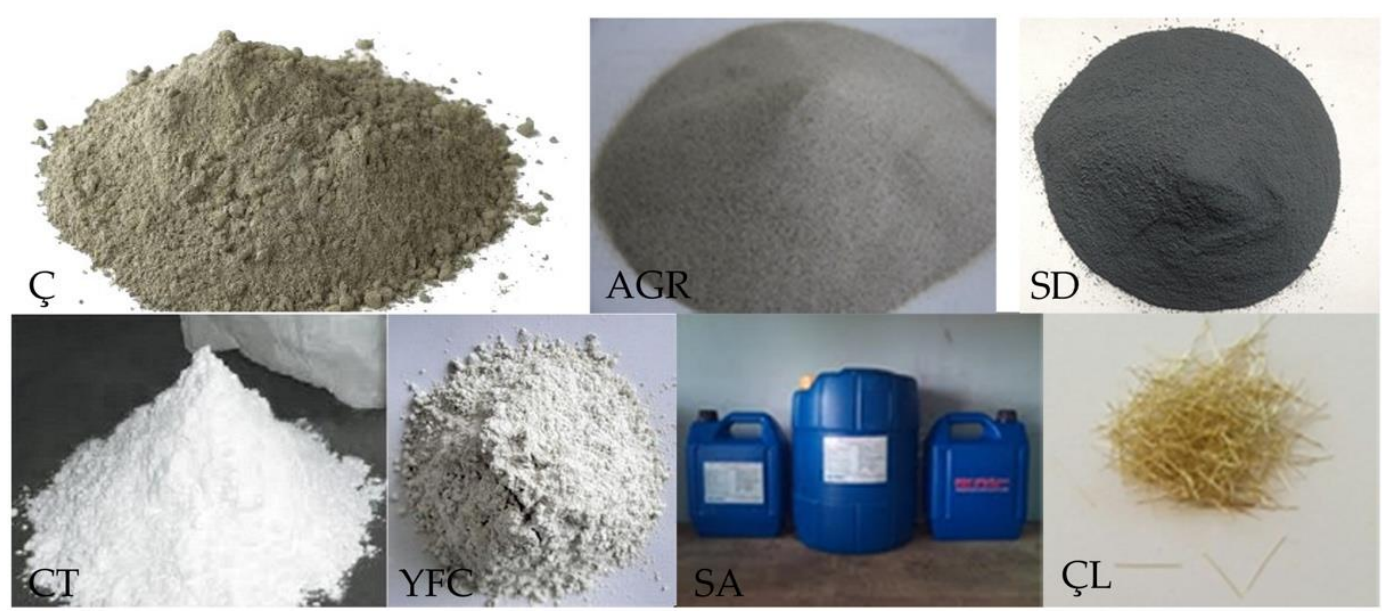

Şekil 2. UYPB'u oluşturan bileşenler.

\subsection{UYPB karışımlarının hazırlanması}

Çimento yerine farklı oranlarda CT ve/veya YFC ikamesinin beton basınç dayanımına üzerindeki etkisi, matristeki toplam bağlayıcı miktarının $1000 \mathrm{~kg} / \mathrm{m}^{3}$ ve su / bağlayıcı oranının 0.19 olduğu UYPB karışımı için araştırılmıştır. Çelik lifsiz ve lifli beton karışımında $1 \mathrm{~m}^{3}$ hacimdeki bileşenlerin ağırlıkları, su / çimento oranları ile betonun işlenebilirlik ve akıcılık parametreleri Tablo 1'de sunulmuştur [41].

Çalışmada, katkısız kontrol karışımı KK olarak kodlanmıştır. Karışıma sadece CT ikame edilmesi halinde $\% 12.5$ ve $\% 25$ oranları, sirasiyla, $\% 12.5 \mathrm{C}$ ve $\% 25 \mathrm{C}$ olarak isimlendirilirken, YFC kullanımları için $\% 12.5 \mathrm{Y}$ ve $\% 25 \mathrm{Y}$ kodları kullanılmıştır. Bununla birlikte, eşit ve farklı oranlarda daha fazla katkı içeren $\% 12.5 \mathrm{CT}+\% 12.5 \mathrm{YFC}$, 
$\% 25 \mathrm{CT}+\% 12.5 \mathrm{YFC}, \% 25 \mathrm{CT}+\% 25 \mathrm{YFC}$ karışımları için benzer kodlama düzeni yapılmıştır. Örneğin, $\% 12.5 \mathrm{C}+\% 12.5 \mathrm{Y}$, çimento yerine ağırlıkça $\% 12.5$ oranında $\mathrm{CT}$ ve YFC'nun ikame edildiği ikili bağlayıcı sistemine sahip beton karışımını ifade etmektedir. Çelik lif içeren karışımların kodlarına ÇL kısaltması eklenmiştir (Tablo 1).

Tablo 1'deki oranlar esas alınarak, UYPB'u oluşturan bileşenler tartıldıktan sonra, 56 $\mathrm{dm}^{3}$ kapasiteli standart bir pan-mixer'de kuru olarak 3 dk karıştırılmıştır (Şekil 3a). Daha sonra, kuru karışıma gerekli suyun tamamı ve SA'nın yarısı ilave edilerek $5 \mathrm{dk}$ daha karıştırılmıştır (Şekil 3b). Plastik kıvamdaki karışıma kalan SA eklendikten sonra, homojen bir karışım elde edilinceye kadar 60 devir/dk'lik sabit hızda karıştırma işlemine devam edilmiştir (Şekil 3c). ÇL içeren karışımlarda, karışım plastik kıvama geldikten sonra topaklanma olmaması için ÇL'ler serpilme şeklinde ilave edilmiş ve karışım homojen oluncaya kadar karıştırılmıştır (Şekil 3d). Hazırlanan lifsiz ve lifli beton karışımları, 100x100x100mm boyutlarındaki plastik küp kalıplara vibrasyon uygulanmadan yerleştirilmiştir (Şekil 3e). Farklı oranlarda CT ve/veya YFC içeren beton karışımlarının işlenebilirlik ve akıcılık özelliklerini belirlemek amacıyla çökmeyayılma (slump flow - SF) testleri ile yayılma tablası üzerindeki $500 \mathrm{~mm}$ 'lik yarıçap sınırına ulaşma süreleri (t-500) lifsiz ve lifli karışımlar için ölçülmüştür (Şekil $3 f$ ve Tablo 1). Döküm işleminden sonra, buharlaşma ile oluşacak su kaybını engellemek için numuneler ince bir plastik örtü ile korunmuştur. 24 saat sonra kalıptan çıkarılan küp numuneler, farklı test günlerine $\left(7,14,28,56\right.$ ve 90) kadar $20 \pm 2^{\circ} \mathrm{C}$ lik laboratuvar koşulunda bekletilmiştir. Döküm işlemi ile ilgili detaylı bilgiye [41] nolu referanstan ulaşılabilir.

Tablo 1. UYPB'u oluşturan bileşenlerin ağırlıkları ve betonun akıcılık özellikleri [41].

\begin{tabular}{|c|c|c|c|c|c|c|c|c|c|c|c|}
\hline Karışım & $\underset{(\mathbf{k g})}{\mathrm{C}}$ & $\begin{array}{l}\text { SD } \\
(\mathbf{k g})\end{array}$ & $\begin{array}{l}\text { CT } \\
(\mathbf{k g})\end{array}$ & $\underset{(\mathbf{k g})}{\text { YFC }}$ & $\underset{(\mathbf{k g})}{\mathrm{Su}}$ & $\begin{array}{l}\text { SA } \\
(\mathbf{k g})\end{array}$ & $\underset{(\mathbf{k g})}{\mathbf{A G R}}$ & $\begin{array}{c}\text { ClL } \\
\text { (kg) }\end{array}$ & $\mathrm{Su} / \mathrm{C}$ & $\underset{(\mathbf{m m})}{\mathbf{S F}}$ & $\begin{array}{c}\mathbf{t}-500 \\
\text { (sn) }\end{array}$ \\
\hline KK & 800 & 200 & --- & --- & 190 & 25 & 1195 & --- & .24 & 980 & 2.3 \\
\hline$\% 12.5$ & 00 & 200 & 100 & --- & 190 & 25 & 1170 & $\begin{array}{l}-- \\
\end{array}$ & 0.27 & 910 & 2.5 \\
\hline$\% 25$ & 600 & 200 & 200 & --- & 190 & 25 & 1145 & --- & 32 & 1000 & 2.2 \\
\hline$\% 12.5 \mathrm{Y}$ & 700 & 200 & $\begin{array}{l}-- \\
-\end{array}$ & 100 & 190 & 25 & 1185 & $\begin{array}{l}-- \\
\end{array}$ & 0.27 & 890 & 2.6 \\
\hline$\% 25 \mathrm{Y}$ & 600 & 200 & --- & 200 & 190 & 25 & 1175 & --- & 0.32 & 850 & 2.6 \\
\hline$\% 12.5 \mathrm{C}-$ & & 200 & 100 & 100 & & 25 & & --- & 32 & 1020 & 2.3 \\
\hline$\% 25 \mathrm{C}+\% 12.5 \mathrm{Y}$ & 500 & 200 & 200 & 100 & 190 & 25 & 1135 & --- & 0.38 & 890 & 2.5 \\
\hline$\% 25 \mathrm{C}+\% 25 \mathrm{Y}$ & 400 & 200 & 200 & 200 & 190 & 25 & 1127 & --- & 0.48 & 1070 & 2.3 \\
\hline $\mathrm{KK}+\mathrm{C} \mathrm{L}$ & 800 & 200 & --- & --- & 190 & 25 & 1170 & 78 & 0.24 & 710 & 3.0 \\
\hline$\% 12.5 \mathrm{C}+\mathrm{ÇL}$ & 700 & 200 & 100 & --- & 190 & 25 & 1145 & 78 & 0.27 & 750 & 3.4 \\
\hline$\% 25 C+C ̧ L$ & 600 & 200 & 200 & --- & 190 & 25 & 1120 & 78 & 0.32 & 830 & 2.8 \\
\hline$\% 12.5 \mathrm{Y}+\mathrm{ÇL}$ & 700 & 200 & --- & 100 & 190 & 25 & 1160 & 78 & 0.27 & 770 & 2.7 \\
\hline$\% 25 \mathrm{Y}+\mathrm{C} \mathrm{L}$ & 600 & 200 & --- & 200 & 190 & 25 & 1150 & 78 & 0.32 & 790 & 2.9 \\
\hline$\% 12.5 \mathrm{C}+\% 12.5 \mathrm{Y}+\mathrm{C \zeta L}$ & 600 & 200 & 100 & 100 & 190 & 25 & & 78 & 0.32 & 770 & 3.2 \\
\hline$\% 25 \mathrm{C}+\% 12.5 \mathrm{Y}+\mathrm{C} L$ & 500 & 200 & 200 & 100 & 190 & 25 & 1110 & 78 & 0.38 & 800 & 2.9 \\
\hline$\% 25 \mathrm{C}+\% 25 \mathrm{Y}+\mathrm{C} L$ & 400 & 200 & 200 & 200 & 190 & 25 & 1100 & 78 & 0.48 & 820 & 2.7 \\
\hline
\end{tabular}




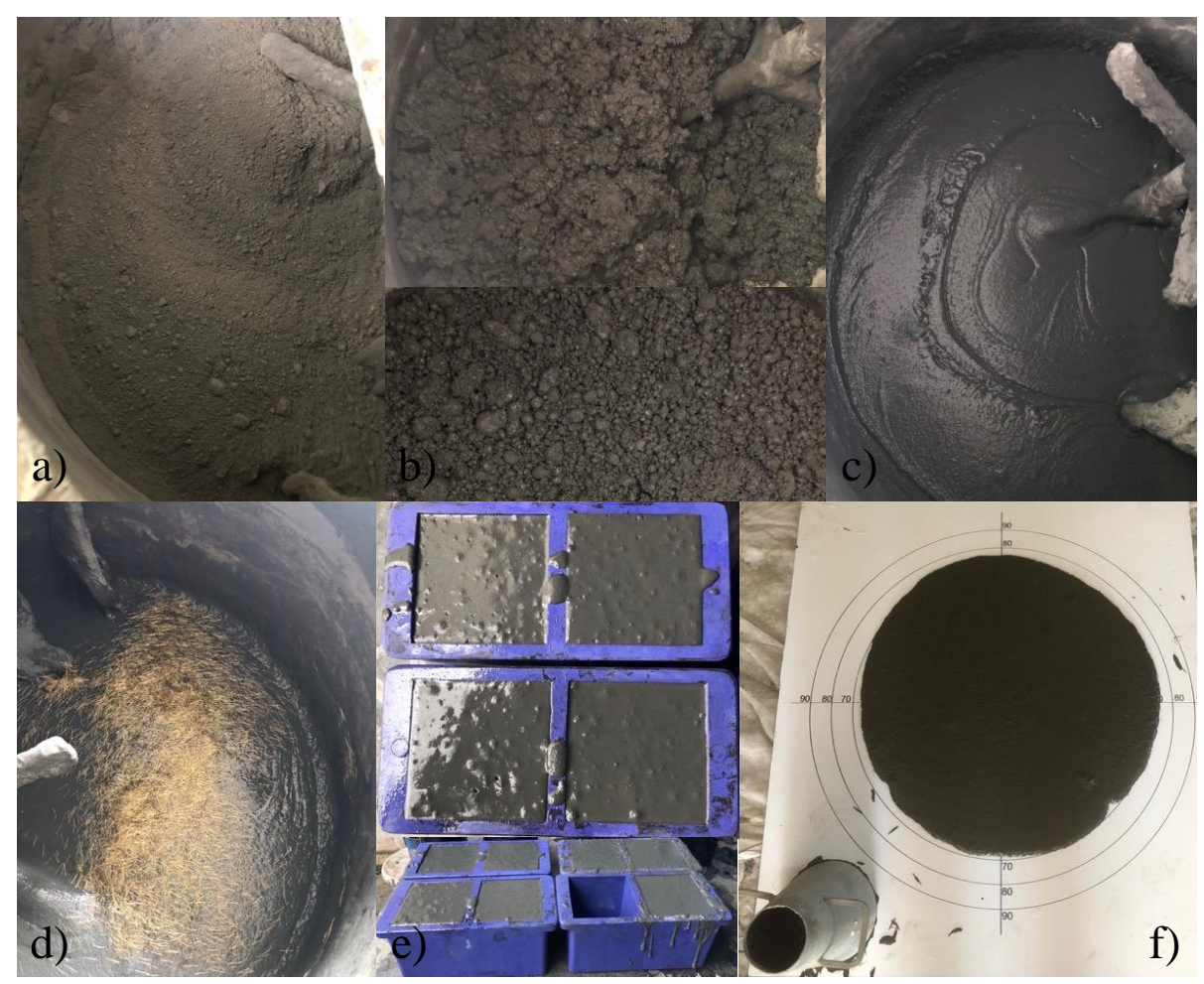

Şekil 3. UYPB'un hazırlanması, a) kuru karışım b) yarı-kuru karışım c) plastik karışım d) çelik lifler e) küp numuneler f) yayılma tablası.

\subsection{Test düzeneği}

Farklı katkı ikameleri için 100x100x100 mm boyutlarında hazırlanan küp numunelerin eksenel basınç testleri, $3000 \mathrm{kN}$ kapasiteli ve yük kontrollü basınç presi yardımıyla yapılmıştır (Şekil 4a-c). 7, 14, 28, 56 ve 90 günlük beton yaşlarında her bir numune grubu için üçer adet hazırlanan küp numunelerin basınç dayanımlarına ait ortalama değerler esas alınmıştır. Tek eksenli basınç testine ait ayrıntılar BS EN 12390-3:2009 [42]'de bulunabilir.

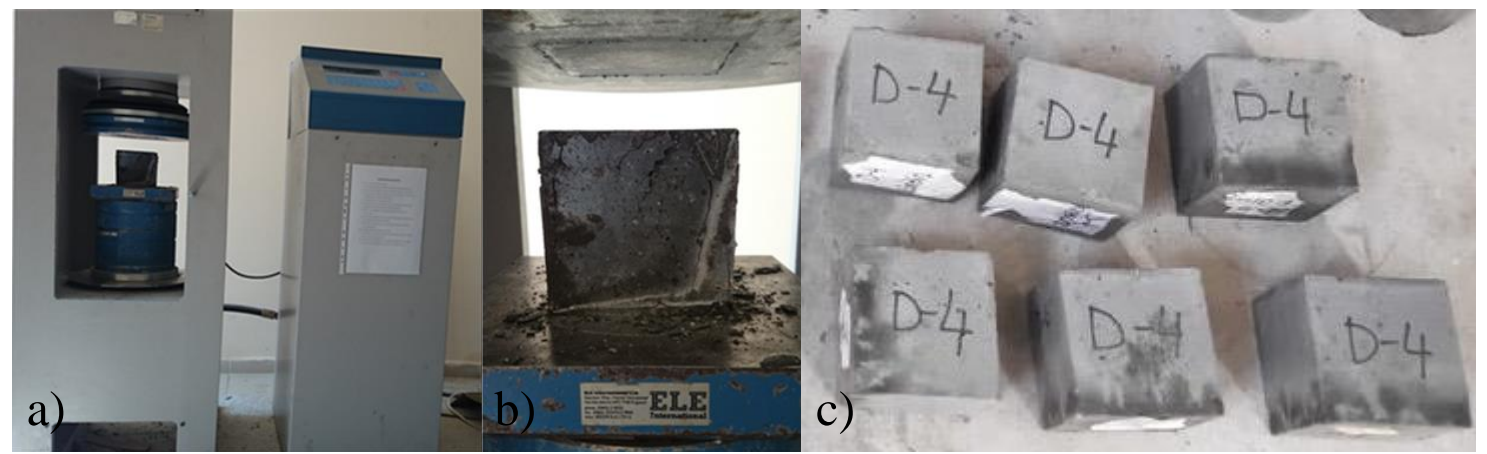

Şekil 4. a) Basınç presi b) test edilen küp numune c) tipik küp numuneleri.

\subsection{Betonun işlenebilirlik ve akıcılık özellikleri}

Kısmi olarak kullanılan katkı malzemelerinin betonun işlenebilirlik ve akıcılık üzerindeki etkileri çökme-yayılma ve t-500 testleri ile belirlenmiştir. Tablo 1'deki taze beton özellikleri incelendiğinde, katkı oranından bağımsız olarak, yayılma değerleri ve t-500 süreleri kontrol karışımına oldukça yakındır. Karışımdaki CT miktarı arttıkça yayılma değerlerinin artış gösterdiği, YFC miktarının ise belirgin bir etkisinin olmadığı 
söylenebilir. Çimento yerine \%50’ye ulaşan oranlarda katkı malzemesi kullanılması ile, kontrol karışımına göre daha işlenebilir ve akıcı bir beton karakteristiği elde edilmiştir. Katkılı beton karışımlarının en az kontrol karışımı kadar işlenebilir olmasının sebebi, CT ve YFC taneciklerinin daha düşük su emme ve daha yumuşak yüzeylere sahip olmasidir.

UYPLB karışımlarında ise, katkısız kontrol karışımındaki yayılma değerleri yaklaşık $\% 27$ azalmakla birlikte, t-500 süreleri \%30 oranında artmıştır (Tablo 1 ). Hacimce $\% 1.0$ lif içeren karışım için yayılma parametresindeki değişim Wu vd. [37]'de yaklaşık \%15 olarak belirlenmiştir. Gözönüne alınan tüm katkı oranları için çelik lifli karışımlara ait yayılma değerleri kontrol karışımından daha fazla olmakla birlikte, katkılı karışımlar arasındaki en büyük değişim $\approx \% 10$ 'dur. Bununla birlikte, çelik lifsiz ve lifli beton karışımlarında CT miktarı arttıkça işlenebiliklik özelliklerinin arttığı ve YFC kullanımına göre lifli betonun daha akıcı olduğu görülmüştür.

\section{Beton basınç dayanımlarına ait sonuçlar ve tartışmalar}

\subsection{Cam tozunun tekil kullanımına ait sonuçlar}

UYPB karışımında, katkısız numune KK ile çimento yerine \%12.5 ve \%25 oranlarında CT'nun ikame edildiği çelik lifsiz test numunelerine ait basınç dayanımlarının beton yaşlarına bağlı değişimi Şekil 5'de verilmiştir. Ayrıca, 28 günlük beton basınç dayanımına göre diğer beton yaşları için elde edilen basınç dayanımlarına ait gerçekleşme oranları $\left(f_{c}^{\prime}\right.$ gün $/ f_{c}^{\prime}{ }^{28}$ ) Tablo 2'de sunulmuştur [41]. İlk olarak, beton yaşına bağlı basınç dayanımlarının değişimleri incelendiğinde, basınç dayanımlarının genel olarak artış eğilimde olduğu görülmektedir. Erken beton yaşlarında dayanımlardaki artışlar daha belirgin iken, ilerleyen yaşlarda bu değişimler daha sınırlı düzeyde kalmıştır (Şekil 5). 28 günlük basınç dayanımlarına göre 56 ve 90 günlük sonuçların en fazla $\% 5$ oranında arttığ belirlenmiştir (Tablo 2).

Karışımlara \%12.5 ve \%25 oranlarında sadece CT ikamesi, özellikle erken ( 7 ve 14 gün) beton yaşlarındaki basınç dayanımlarını belirgin bir şekilde azaltııştır (Şekil 5). $\% 25+\mathrm{CT}$ 'nun kullanıldığ 1 bu numunelerde kontrol numunesine göre \%26'ya ulaşan dayanım kayıpları oluşmasına karşın, beton yaşı arttıkça kontrol numunesine yakın sonuçlar elde edilmiştir. $\% 12.5$ ve $\% 25$ oranlarında CT ikamesi, 28 günlük basınç dayanımlarını kontrol numunesine göre $\% 4$ ve $\% 8$ azalırken, 56 ve 90 günlük ilerleyen beton yaşlarında $\% 12.5+\mathrm{CT}$ içeren numuneye ait dayanımlar kontrol numunesine çok yakındır. $\% 25+\mathrm{CT}$ numunesinin ilerleyen yaşlardaki basınç dayanımları $\approx \% 8$ azalmıştır. Özellikle erken beton yaşlarında UYPB numunelerinin basınç dayanımlarında kontrol numunelerine göre bir miktar azalmalar olabilmesine karşın, çelik lifsiz UYPB için hedeflenen basınç dayanımına her iki CT miktarı için de ulaşılmıştır (Şekil 5 ve Tablo 2). 


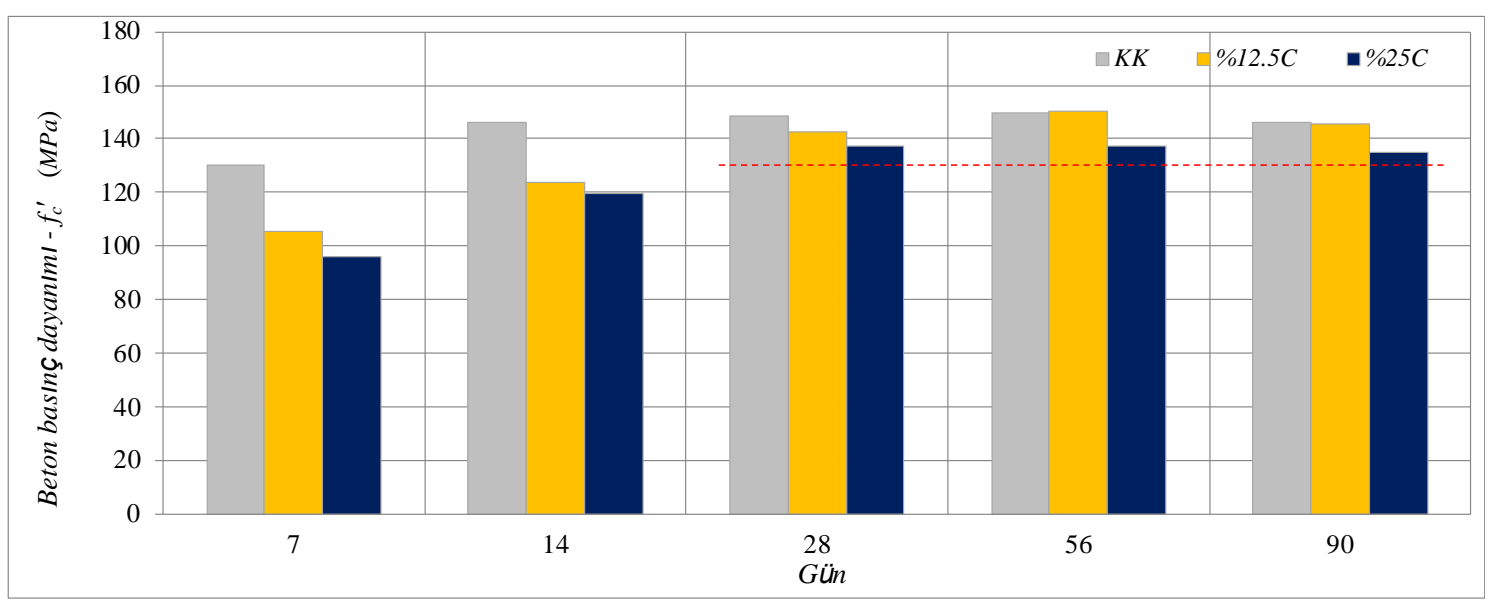

Şekil 5. CT’nun tekil kullanımına ait beton basınç dayanımları.

Tablo 2. Farklı oranlarda katkı kullanımları için 28 günlük basınç dayanımına göre diğer beton yaşlarının gerçekleşme oranları.

\begin{tabular}{|c|c|c|c|c|c|c|c|c|c|c|c|c|}
\hline \multirow{3}{*}{$\begin{array}{l}\text { Numune } \\
\text { KK }\end{array}$} & \multirow{3}{*}{$\left.\begin{array}{l}C T \\
(\%)\end{array}\right)$} & \multirow{3}{*}{$\begin{array}{c}\boldsymbol{Y} F C \\
(\%)\end{array}$} & \multirow{3}{*}{$\begin{array}{l}C \zeta L \\
(\%) \\
--\end{array}$} & \multicolumn{5}{|c|}{$f_{c}^{\prime}(\mathrm{MPa})$} & \multicolumn{4}{|c|}{$f_{c}^{\prime}$ gün $/ f_{c}{ }^{\prime 28}$} \\
\hline & & & & \multicolumn{2}{|c|}{7} & \multicolumn{2}{|c|}{14} & \multirow{2}{*}{$\begin{array}{c}\mathbf{2 8} \\
148.8\end{array}$} & \multicolumn{2}{|c|}{56} & \multicolumn{2}{|c|}{90} \\
\hline & & & & 130.2 & 0.88 & 146.4 & 0.98 & & 149.5 & 1.00 & 146.0 & 0.98 \\
\hline$\% 12.5 \mathrm{C}$ & 12.5 & $\begin{array}{l}-- \\
-\end{array}$ & --- & 105.5 & 0.74 & 123.6 & 0.88 & 142.5 & 150.2 & 1.05 & 145.5 & 1.02 \\
\hline$\% 25 \mathrm{C}$ & 25 & --- & --- & 96.1 & 0.70 & 119.7 & 0.87 & 137.1 & 137.1 & 1.00 & 134.8 & 0.98 \\
\hline$\% 12.5 \mathrm{Y}$ & --- & 12.5 & --- & 108.9 & 0.81 & 122.3 & 0.91 & 134.0 & 135.2 & 1.01 & 142.9 & 1.07 \\
\hline$\% 25 \mathrm{Y}$ & --- & 25 & --- & 103.2 & 0.76 & 126.5 & 0.93 & 135.4 & 145.3 & 1.07 & 141.0 & 1.04 \\
\hline$\% 12.5 \mathrm{C}+\% 12.5 \mathrm{Y}$ & 12.5 & 12.5 & --- & 95.6 & 0.75 & 114.4 & 0.89 & 128.0 & 133.0 & 1.04 & 138.5 & 1.08 \\
\hline$\% 25 \mathrm{C}+\% 12.5 \mathrm{Y}$ & 25 & 12.5 & --- & 91.8 & 0.72 & 107.4 & 0.85 & 126.8 & 129.1 & 1.02 & 130.5 & 1.03 \\
\hline$\% 25 \mathrm{C}+\% 25 \mathrm{Y}$ & 25 & 25 & --- & 82.0 & 0.74 & 93.7 & 0.85 & 110.5 & 114.8 & 1.04 & 124.3 & 1.12 \\
\hline
\end{tabular}

\subsection{Yüksek firın cürufunun tekil kullanımına ait sonuçlar}

Çimento yerine \%12.5 ve \%25 oranlarında sadece YFC'nun ikame edildiği çelik lifsiz UYPB numunelerine ait basınç dayanımlarının değişimi Şekil 6'da verilmiştir [41]. Sadece CT ikame edilen numunelerde olduğu gibi, YFC içeren numunelere ait basınç dayanımları erken beton yaşlarında hızlı artış eğiliminde iken, 56 ve 90 günlük dayanımlardaki değişimlerin sabit kaldığı gözlenmiştir (Şekil 6). 28 günlük test sonuçları referans alındığında, \%12.5 ve \%25 YFC'li numunelere ait 56 günlük basınç dayanımları sırasıyla $\% 3$ ve $\% 5,90$.günde ise $\% 3$ ve $\% 15$ oranlarında artmıştır (Tablo 2). Farklı beton yaşları için basınç dayanımlarındaki bu değişim, Yazıcı [36] ve Yalçınkaya ve Yazıcı [31]'de elde edilenlerle farklılık göstermektedir. İlgili çalışmalarda, çimento yerine \%12.5'a kadar YFC kullanımı basınç dayanımlarını çok az oranda $(<\% 5)$ artırmasına karşın, daha yüksek YFC oranları için basınç dayanımlarında ani azalmalar görülmüştür.

$\% 12.5$ ve $\% 25$ oranlarında tekli ikame edilen YFC, beton basınç dayanımlarını kontrol numunesine göre azaltmıştır. 7 ve 14 günlük erken beton yaşlarındaki değişimler en fazla $\% 21$ iken, 28, 56 ve 90.günlerde en fazla \%10 oranındadır (Tablo 2). Kontrol numunesine göre erken yaşlardaki basınç dayanımlarındaki azalımlar CT kullanımına göre daha az iken, ilerleyen beton yaşlarında CT kullanımı kontrol numunesine daha yakın sonuç vermiştir. Karışımdaki YFC miktarının \%12.5'den \%25 artırılmasının, erken ve ilerleyen yaşlardaki basınç dayanımında pozitif/negatif bir etkisinin olmadığı 
sonucu çıkarılabilir (Şekil 6). Çelik lifsiz UYPB içeriğinde çimento yerine her iki oranda YFC ikamesi ile oldukça üniform bir davranışın oluştuğu belirlenmiştir. Bu bağlamda, katkı miktarından bağımsız olarak, 28 ve 90.günlerdeki basınç dayanımları sirasiyla $\approx 135$ ve $140 \mathrm{MPa}$ 'dır.

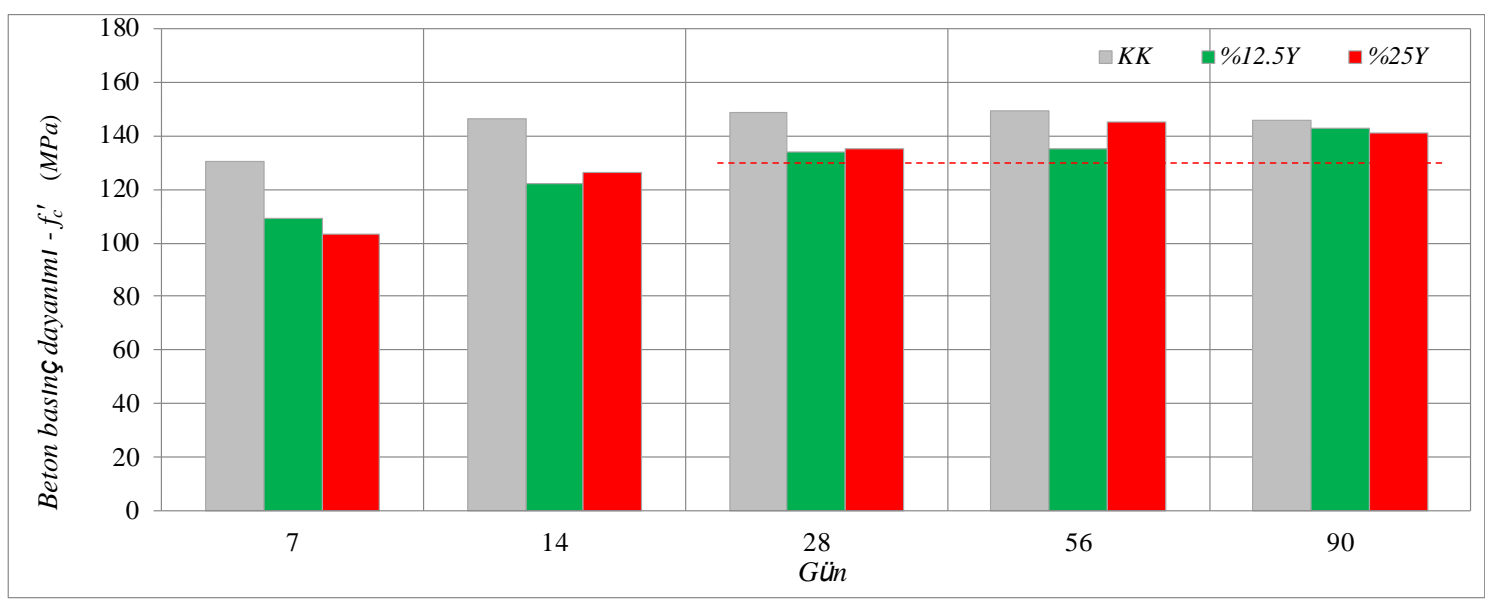

Şekil 6. YFC'nun tekil kullanımına ait beton basınç dayanımları.

\subsection{Cam tozu ve yüksek fırın cürufunun ikili kullanımına ait sonuçlar}

UYPB'da ilgili katk1 malzemelerinin daha yüksek oranlarda ikame edilip edilmeyeceğini araştırmak amacıyla, CT ve YFC'nun eşit ve farklı oranlarda ikili olarak kullanıldığ $(\% 12.5 \mathrm{C}+\% 12.5 \mathrm{Y} ; \% 25 \mathrm{C}+\% 12.5 \mathrm{Y}$ ve $\% 25 \mathrm{C}+\% 12.5 \mathrm{Y})$ numunelerin $7-90$ günlerdeki basınç dayanımlarının değişimi Şekil 7'de sunulmuştur [41].

Toplamda \%25, \%37.5 ve \%50 oranlarında CT ve YFC'nun ikili kullanıldı̆̆ karışımlarında katkı malzemelerinin basınç dayanımlarını olumsuz etkilediği, katkı oranı arttıkça dayanımların hızla azalan bir eğilim gösterdiği belirlenmiştir (Şekil 7). Kontrol numunelerine göre dayanımlardaki bu azalım erken beton yaşlarında en fazla $\% 37$ iken, 28, 56 ve 90. günlerde ise sirasiyla en fazla $\% 26, \% 23$ ve $\% 17$ oranlarındadır. $\mathrm{Bu}$ noktada, $\% 37.5$ katkı içeren $\% 25 \mathrm{C}+\% 12.5 \mathrm{Y}$ numunesi hedef dayanıma ait sınıra çok yakın iken, CT ve YFC'nun eşit olarak kullanıldı̆̆ $\% 25 \mathrm{C}+\% 25 \mathrm{Y}$ numunesinde hedef basınç dayanımına ulaşamamıştır (Şekil 7). \%50 oranında katkı içeren bu numunenin basınç dayanımı $\approx 124 \mathrm{MPa}$ olmakla birlikte, 28 günlük sonuçlara göre 56 ve 90 günlük basınç dayanımları, sırasıyla, $\% 4$ ve $\% 12$ artmıştır (Tablo 2). Bu sonuç 1şığında, 120 gün gibi daha ileri bir beton yaşında hedef basınç dayanımına ulaşacağı düşünülmektedir. Yüksek oranlarda katkı içeren numunelerde gözlenen dayanım azalımları, Yazıcı [36] ve Yalçınkaya ve Yazıcı [31]'deki sonuçlarla oldukça uyumludur. 


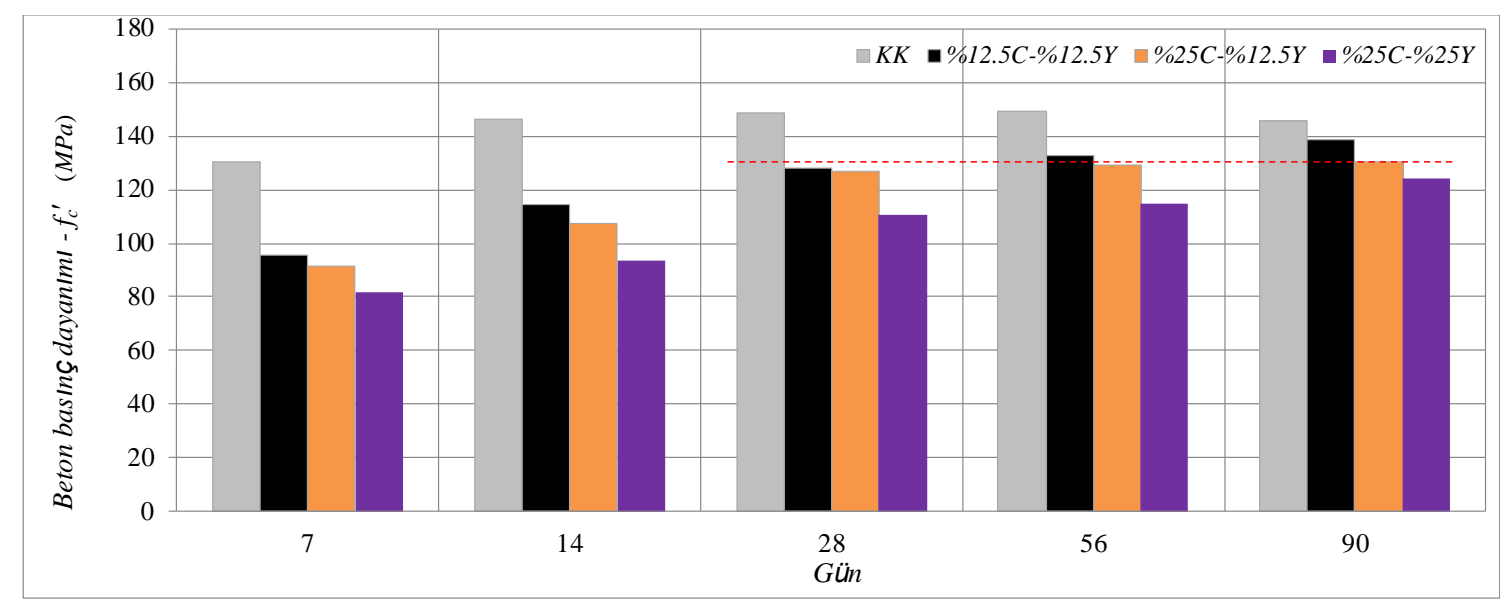

Şekil 7. UYPB'da CT ve YFC'nun ikili kullanımlarına ait basınç dayanımları.

\section{4. Çelik lif kullanımına ait sonuçlar}

Deneysel çalışma kapsamında, farklı oranlarda CT ve/veya YFC ikameli UYPB karışımlarına hacimsel olarak \%1.0 oranında eklenen çelik liflerin beton basınç dayanımına etkisi ve ayrıca, lifli beton karışımlarında sözkonusu katkıların basınç dayanımı üzerindeki etkileri araştırılmıştır [41].

Çelik liflerin basınç dayanımı üzerindeki etkilerini karşılaştırmalı gösteren Şekil 8'deki değişimler incelendiğinde, katkısız beton karışımına çelik liflerin eklenmesi genel olarak basınç dayanımlarını azaltmıştır. Bu değişimler, 7, 14 ve 28 günler için sırasıyla $\% 5, \% 12$ ve $\% 10$ iken, 56 ve 90 günlük beton yaşlarında daha küçük olduğu $(<\% 5)$ belirlenmiştir. Buna karşın, farklı oranlarda CT ve YFC'nun bağımsız veya birlikte ikame edildiği çelik lifli numunelerin basınç dayanımları erken beton yaşlarında \%35'e ulaşan oranlarda artmıştır. Beton karışımında daha yüksek oranda katkı kullanılmasıyla liflerin basınç dayanımı üzerindeki etkinliği daha önem kazanmıştır. Ayrıca, YFC kullanımına kıyasla CT içeren karışımlarda çelik liflerin kazandırdığı katkı daha fazladır (Şekil 8). \%12.5 veya \%25 oranlarında sadece CT veya YFC ikame edilmiş beton karışımlarına çelik lif eklenmesi sonucunda 28 günlük basınç dayanımları çok az oranda azalırken $(<\% 5)$, CT ve YFC'nun eşit oranlarda kullanıldığı test numunelerine $(\% 12.5 \mathrm{C}+\% 12.5 \mathrm{Y}$ ve $\% 25 \mathrm{C}+\% 25 \mathrm{Y})$ ait dayanımlar sırasıyla $\% 6$ ve $\% 15$ artmıştır. $\% 25 \mathrm{CT}+\% 12.5 \mathrm{YFC}$ içeren numunede ise kontrol numunesine çok yakın bir sonuç elde edilmiştir. Bununla birlikte, \%12.5+CT içeren beton karışımı dışında çelik liflerin 56 ve 90 günlük beton basınç dayanımlarını \%19'e ulaşan oranlarda artırdığı belirlenmiştir. Karışıma çelik liflerin eklenmesi ile basınç dayanımlardaki genel artış eğiliminin sebebi, [37,40,43] nolu referanslarda lif içeriğinin yüzey alanını artması olarak açıklanmaktadır. Farklı oranlarda katkı içeren lifli numunelerin 28 günlük basınç dayanımları 140 MPa'lık hedef bandın altında kalmasına karşın, \%25Y+ÇL ve $\% 25 \mathrm{C}+\% 12.5 \mathrm{Y}+\mathrm{C} L \mathrm{~L}$ dışındaki tüm numunelerde 90 .günde hedef dayanıma ulaş1lmıştır. Çelik liflerin basınç dayanımı üzerindeki sağladığı en büyük katkı, ağırlıkça \%25CT +\%25YFC'nun ikame edildiği \%50 katkılı numunede elde edilmiştir (Şekil 8). 


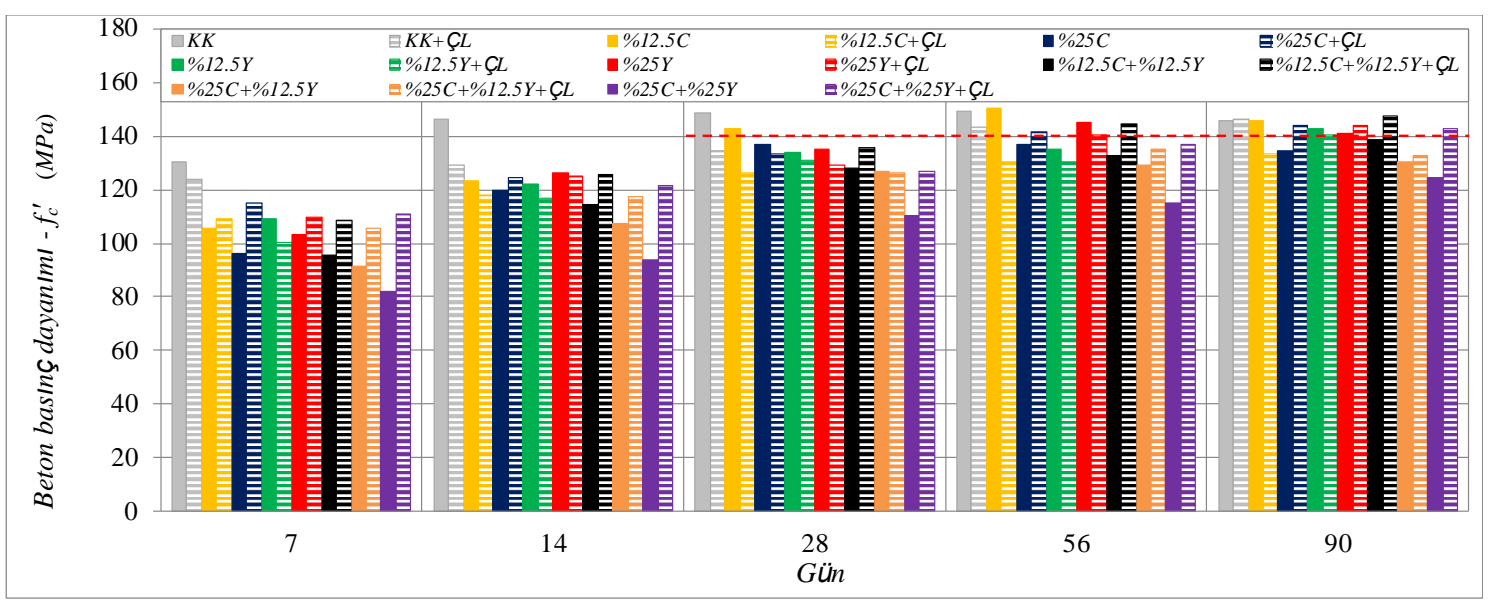

Şekil 8. UYPB'da çelik liflerin beton basınç dayanımına etkisi.

Diğer taraftan, UYPLB karışımlarında katkı malzemlerinin bağımsız veya birlikte kullanımlarının basınç dayanımı üzerindeki etkinliği Şekil 9'da, 28 günlük sonuçlara göre diğer beton yaşlarındaki gerçekleşme oranları Tablo 3'de sunulmuştur [41]. Çelik lifli katkısız beton karışımlarına \%12.5-\%50 arasında CT ve YFC ikameleri sonucunda, 7 günlük ortalama basınç dayanımları \%12, 14.günde $\% 6,28$ ve daha ileri beton yaşlarında ise \%3-\%4 seviyelerinde azalmıştır. Bununla birlikte, CT veya YFC'nun \%25'e çıkması halinde dayanımlar artış eğilimine geçmesine karşın, genel olarak, kontrol numunelerinin altında kalmıştır (Şekil 9). CT ve YFC'nun eşit miktarda kullanıldığ $\% 12.5 \mathrm{C}+\% 12.5 \mathrm{Y}+\mathrm{ÇL}$ numunenin 28 ve daha ileri günlerdeki dayanımları kontrol karışımına çok yakındır. Katkı malzemelerinin daha yüksek oranlarda kullanıldığ $1 \% 25 \mathrm{C}+\% 12.5 \mathrm{Y}+\mathrm{C} L$ ve $\% 25 \mathrm{C}+\% 25 \mathrm{Y}+\mathrm{ÇL}$ numuneler için elde edilen basınç dayanımları kontrol numunelerine kıyasla daha küçük olmakla birlikte, beton yaşı arttıkça dayanımlardaki değişimler $<\% 5$ seviyelerine inmektedir (Şekil 9 ve Tablo 3). Lifli karışımlarda, 28 günlük beton basınç dayanımlarına gerçekleşme oranlarının erken yaşlarda daha hızlı olduğu, ilerleyen yaşlarda ise sınırlı kaldığı görülmüştür. Burada, 56 ve 90 günler için test sonuçlarının sırasıyla, en fazla $\% 9$ ve \%13 oranlarında arttığı belirlenmiştir (Tablo 3). UYPLB'da CT ve YFC'nun farklı oranlarda kullanımına iliş̧in bu sonuçlar, [44] ve [31]'deki çalışmalarla uyumluluk göstermektedir. CT ile ilgili çalışmada [44], UYPLB karışımında CT kullanımının erken yaşlarındaki basınç dayanımlarını azalttığı, ilerleyen günlerdeki basınç dayanımlarında artış olmasına karşın katkısız kontrol numunesinin altında kaldığ 1 belirlenmiştir. Diğer taraftan, çimento yerine \%50YFC kullanımı sonucunda elde edilen 28 günlük basınç dayanımının kontrol karışımına çok yakın olduğu [31]'de belirlenmiştir.

UYPB karışımlarına farklı oranlarda CT ve/veya YFC ikame edilmesi, genel olarak, erken ve 28 günlük basınç dayanımlarında belirli azalmalara neden olmakla birlikle, 90 günlük ileri beton yaşında katkı malzemelerine ilişkin sonuçlar birbirleriyle oldukça uyumludur. Çelik lifli UYPLB karışımlarına ait sonuçlar izlendiğinde, 7 - 90 arasındaki günlerin büyük bir bölümünde basınç dayanımlara ilişkin sonuçların oldukça yakın karakter gösterdiği belirlenmiştir (Şekil 9). 


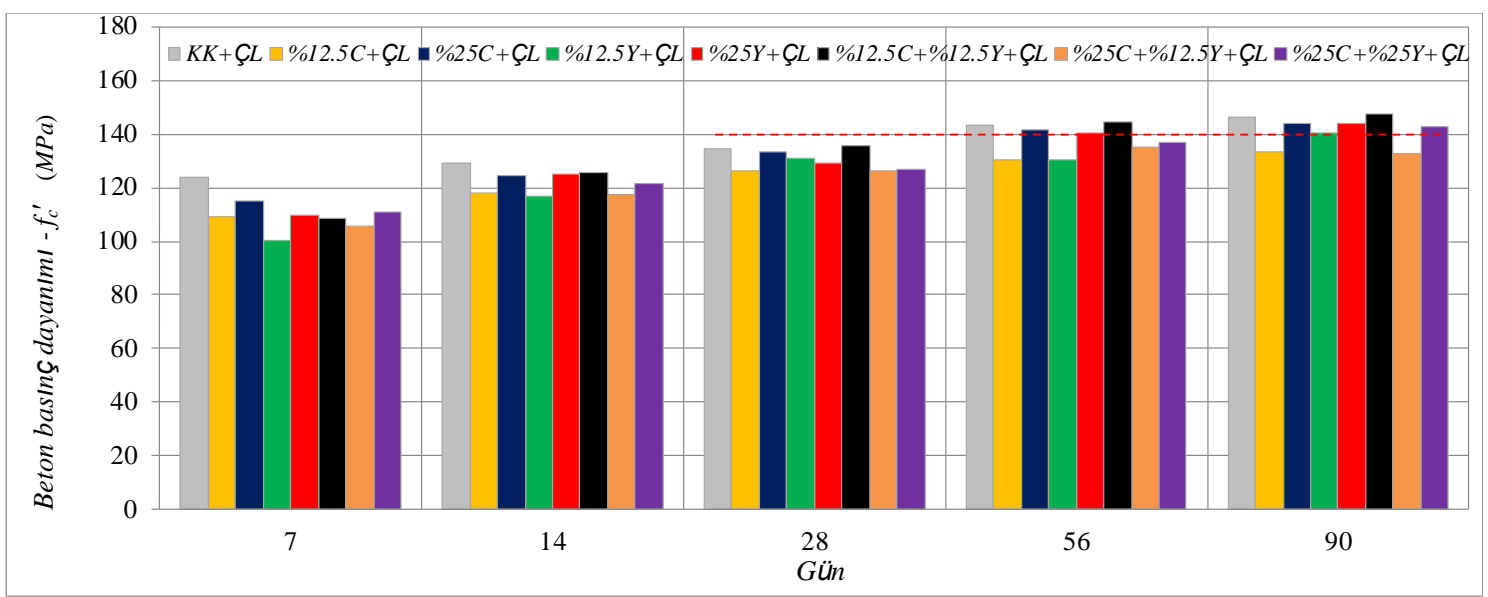

Şekil 9. UYPLB'un basınç dayanımı üzerinde CT ve/veya YFC kullanımlarının etkisi.

Tablo 3. UYPLB numunelerinde 28 günlük basınç dayanımına göre gerçekleşme oranları.

\begin{tabular}{|c|c|c|c|c|c|c|c|c|c|c|c|c|}
\hline \multirow{3}{*}{$\begin{array}{l}\text { Numune } \\
\mathrm{KK}+C ̧ \mathrm{~L}\end{array}$} & \multirow{3}{*}{$\begin{array}{l}C T \\
(\%)\end{array}$} & \multirow{3}{*}{$\begin{array}{c}\boldsymbol{Y} \boldsymbol{F} \\
\boldsymbol{C} \\
--\end{array}$} & \multirow{3}{*}{$\begin{array}{l}\text { ÇL } \\
(\%) \\
1.0\end{array}$} & \multicolumn{9}{|c|}{$f_{c}^{\prime}(\mathrm{MPa})-f_{c}^{\prime}$ gün $/ f_{c}{ }^{\prime 28}$} \\
\hline & & & & \multicolumn{2}{|c|}{7} & \multicolumn{2}{|c|}{14} & \multirow{2}{*}{$\frac{\mathbf{2 8}}{134.6}$} & \multicolumn{2}{|c|}{56} & \multicolumn{2}{|c|}{90} \\
\hline & & & & 123.8 & 0.92 & 129.1 & 0.96 & & 143.2 & 1.06 & 146.5 & 1.09 \\
\hline$\% 12.5 \mathrm{C}+\mathrm{C} \mathrm{L}$ & 12.5 & --- & 1.0 & 109.4 & 0.87 & 118.2 & 0.93 & 126.1 & 130.4 & 1.03 & 133.5 & 1.06 \\
\hline$\% 25 \mathrm{C}+\mathrm{C} L$ & 25 & --- & 1.0 & 114.8 & 0.86 & 124.4 & 0.93 & 133.3 & 141.6 & 1.06 & 144.0 & 1.08 \\
\hline$\% 12.5 \mathrm{Y}+\mathrm{C} \mathrm{L}$ & --- & 12.5 & 1.0 & 100.4 & 0.77 & 117.1 & 0.89 & 131.1 & 130.4 & 0.99 & 140.6 & 1.07 \\
\hline$\% 25 \mathrm{Y}+\mathrm{ÇL}$ & --- & 25 & 1.0 & 109.7 & 0.85 & 124.9 & 0.97 & 129.1 & 140.6 & 1.09 & 144.1 & 1.12 \\
\hline$\% 12.5 \mathrm{C}+\% 12.5 \mathrm{Y}+\mathrm{ÇL}$ & 12.5 & 12.5 & 1.0 & 108.4 & 0.80 & 125.6 & 0.93 & 135.5 & 144.8 & 1.07 & 147.5 & 1.09 \\
\hline$\% 25 \mathrm{C}+\% 12.5 \mathrm{Y}+\mathrm{C} \mathrm{L}$ & 25 & 12.5 & 1.0 & 105.4 & 0.84 & 117.5 & 0.93 & 126.0 & 134.9 & 1.07 & 132.5 & 1.05 \\
\hline$\% 25 \mathrm{C}+\% 25 \mathrm{Y}+\mathrm{CCL}$ & 25 & 25 & 1.0 & 111.0 & 0.87 & 121.5 & 0.96 & 127.0 & 137.1 & 1.08 & 142.9 & 1.13 \\
\hline
\end{tabular}

\section{Sonuçlar}

Bir seri parametrik incelemelerin sunulduğu çalışmada, çelik lifsiz ve lifli UYPB karışımlarında çimento yerine farklı oranlarda CT ve/veya YFC ikamelerinin beton basınç dayanımı üzerindeki etkileri araştırılmıştır. \%12.5-\%50 arasında farklı oranlarda katkı içeren test numunelerinin basınç dayanımları kontrol numuneleri referans alınarak değerlendirilmiştir. Deneysel çalışma kapsamında üretilen beton numunelerinden elde edilen başlıca sonuçlar aşağıda sunulmuştur.

- Çimento yerine ağırlıkça \%50'ye ulaşan oranlarda katkı malzemesi kullanılması ile, kontrol karışımına göre daha işlenebilir ve akıcı bir beton karakteristiği elde edilmiştir. Burada, CT'nun taze betonun işlenebilirliğine sağladığı pozitif katkı YFC'ye göre daha fazladır.

- UYPB karışımında \%12.5 ve \%25 oranlarında CT ikamesi, 28 günlük basınç dayanımlarını kontrol numunesine göre $\% 4$ ve $\% 8$ azalırken, 56 ve 90 günlük sonuçlar kontrol numunesine oldukça yakındır. Benzer şekilde, tekil olarak ikame edilen YFC, basınç dayanımlarını kontrol numunesine göre azaltmıştır. Erken beton yaşlarında bu değişimler en fazla $\% 21$ iken, 28 ve daha ileri günlerde en fazla $\% 10$ 'dur. YFC miktarının \%12.5'den \%25'e artırılması, beton basınç dayanımında 
belirgin bir etki oluşturmamıştır. Buna karşın, UYPB için hedeflenen basınç dayanımına her iki CT ve YFC miktarı için ulaşılmıştır.

- \%25, \%37.5 ve \%50 oranlarında CT ve YFC'nun ikili kullanıldığı UYPB'da, katk1 malzemelerinin basınç dayanımlarını olumsuz etkilediği ve katkı oranı arttıkça dayanımların hızla azalan bir eğilimde olduğu belirlenmiştir. Çimento yerine $\% 25$ 'in üzerinde katkı malzemesi kullanılması sonucunda elde edilen 28 günlük basınç dayanımları çoğunlukla $130 \mathrm{MPa}$ 'lık bandın altında kalmasına karşın, 90.günde $\% 25 \mathrm{C}+\% 25 \mathrm{Y}$ dışında $\left(f_{c}^{\prime} \approx 124 \mathrm{MPa}\right)$ hedeflenen performansa ulaşılmıştır.

- Katkısız beton karışımına çelik liflerin eklenmesi 7, 14 ve 28 günlük basınç dayanımlarını \%12'ye ulaşan oranlarda azaltmasına karşın, 56 ve 90 günlük dayanımlar üzerinde çelik liflerin belirgin bir etkisi olmamıştır. Beton karışımında yüksek oranlarda katkı kullanılmasıyla liflerin basınç dayanımı üzerindeki etkisi daha önem kazanmıştır. Basınç dayanımı üzerinde sağlanan en büyük katkı, \%25CT +\%25YFC'nun birlikte ikame edildiği \%50 katkılı numunede elde edilmiştir.

- Çelik lifli katkısız UYPB karışımlarına \%12.5-\%50 arasında CT ve YFC ikamesi sonucunda, 7 ve 14 günlük basınç dayanımları sırasıyla ortalama $\% 12$ ve $\% 6$ azalırken, 28 ve daha ileri günlerdeki değişimler \%3-4 seviyesindedir. CT veya YFC'nun \%25'e çıkarılması halinde dayanımlar artış eğilimine geçmesine karşın, kontrol numunesinin altında kalmıştır. CT ve YFC'nun eşit miktarda kullanıldığ $\% 12.5 \mathrm{C}+\% 12.5 \mathrm{Y}+\mathrm{ÇL}$ numunesinin 28 ve daha ileri günlerdeki dayanımları kontrol karışımına çok yakındır. Daha yüksek oranlarda katkının kullanıldığı karışımlara ait basınç dayanımları kontrol numunelerine göre daha küçük olmakla birlikte, beton yaşı arttıkça dayanımlardaki değişimler $<\% 5$ seviyelerine inmektedir.

Sunulan parametrik incelemeler 1şı̆̆ altında, daha çevre dostu ve ekonomik UYPB elde etmek amaciyla çimento yerine \%50'ye ulaşan oranlarda sözkonusu katkı malzemeleri ikame edilerek hedef dayanımlara ulaşılabileceği görülmüştür. Beton karışımına çelik lif eklenmesi ile bu katkı malzemelerinin basınç dayanımı üzerindeki etkileri daha belirgin hale gelmektedir.

\section{Kaynaklar}

[1] Hassan, A.M.T., Jones S.W. ve Mahmud, G.H., Experimental test methods to determine the uniaxial tensile and compressive behaviour of ultra high performance fibre reinforced concrete (UHPFRC), Construction and Building Materials, 37, 874-882, (2012).

[2] Rossi, P., Influence of fibre geometry and matrix maturity on the mechanical performance of ultra high-performance cement-based composites, Cement and Concrete Composites, 37, 246-248, (2013).

[3] Yu, R., Spiesz, P. ve Brouwers, H.J.H., Development of an eco-friendly ultrahigh performance concrete (UHPC) with efficient cement and mineral admixtures uses, Cement and Concrete Composites, 55, 383-394, (2015).

[4] Turker, K., Hasgul, U., Birol, T., Yavas, A. ve Yazici, H., Hybrid fiber use on flexural behavior of ultra high performance fiber reinforced concrete beams, Composite Structures, 229, 111400, (2019). 
[5] Yavas, A., Hasgul, U., Turker, K. ve Birol, T., Effective fiber type investigation on the shear behavior of ultrahigh-performance fiber-reinforced concrete beams, Advances in Structural Engineering, 22, 7, 1591-1605, (2019).

[6] Hasgul, U., Yavas, A., Birol, T. ve Turker, K., Steel fiber use as shear reinforcement on I-shaped UHP-FRC beams, Applied Sciences, 9, 5526, (2019).

[7] Wille, K., Naaman, A.E. ve Parra-Montesinos, G.J., Ultra-high performance concrete with compressive strength exceeding $150 \mathrm{MPa}(22 \mathrm{ksi})$ : A simpler way, ACI Materials Journal, 108, 1, 46-54, (2011).

[8] Moreillon, L. ve Menetrey, P., Rehabilitation and strengthening of existing RC structures with UHPFRC: Various application, Proceedings, RILEM-fibAFGC Int. Symposium on Ultra-High Performance Fibre-Reinforced Concrete, 127-136, Marseille, France, (2013).

[9] Hasgul, U., Turker, K., Birol, T. ve Yavas, A., Flexural behavior of ultra-highperformance fiber reinforced concrete beams with low and high reinforcement ratios, Structural Concrete, 19, 1577-1590, (2018).

[10] Turker, K., Birol, T., Yavas, A., Hasgul, U. ve Yazici, H., Flexural behavior of beams with ultra high performance fiber reinforced concrete, Technical Journal, 30, 8777-8801, (2019).

[11] Park, J-S., Kim, Y.J., Cho, J-R. ve Jeon, S-J., Early-Age strength of ultra high performance concrete in various curing conditions, Materials, 8, 5537-5553, (2015).

[12] Taşdemir, M.A. ve Bayramov, F., Yüksek performanslı çimento esaslı kompozitlerin mekanik davranışı, itüdergisi/d, mühendislik serisi, 1, 2, 125144, (2002).

[13] AFGC/SETRA, Ultra high performance fibre-reinforced concretes, Association Française de Génie Civil / Service d'études techniques des routes et autoroutes, France, (2013).

[14] Yavas, A., Birol, T., Türker, K., Hasgül, U. ve Yazıc1, H., Improvement on flexural performance of UHPFRC with hybrid steel fiber, Technical Journal, 31, 6, 10379-10397, (2020).

[15] Betterman, L.R., Ouyang, C. ve Shah, S.P., Fiber-matrix interaction in microfiber-reinforced mortar, Advanced Cement Based Materials, 2, 2, 53-61, (1995).

[16] Rossi, P., Ultra high performance fibre reinforced concretes (UHPFRC): An overview, Proceedings, Fifth RILEM Symposium on fibre reinforced concretes (FRC), 87-100, Lyon, France, (2000).

[17] Kocatürk, A.N., Haberveren, S., Aslan, E.G. ve Taşdemir, M.A., Özel prefabrike elemanların ultra yüksek performanslı betonlarla üretimi, Proceedings, 6. Ulusal Beton Kongresi, 447-458, İstanbul, Türkiye, (2005).

[18] Graybeal, B.A., Flexural behavior of an ultrahigh-performance concrete I-girder, Journal of Bridge Engineering, 13, 6, 602-10, (2008).

[19] JSCE, Recommendations for design and construction of ultra-high strength fiber reinforced concrete structures (Draft), JSCE Guidelines for Concrete No. 9, Japan Society of Civil Engineers, Tokyo, Japan, (2006). 
[20] Habel, K. ve Gauvreau, P., Response of ultra-high performance fiber reinforced concrete (UHPFRC) to impact and static loading, Cement Concrete Composites, 30, 10, 938-946, (2008).

[21] Yoo, D.Y., Lee, J.H. ve Yoon, Y.S., Effect of fiber content on mechanical and fracture properties of ultra high performance fiber reinforced cementitious composites, Composite Structures, 106, 742-753, (2013).

[22] Fehling, E., Schmidt, M., Walraven, J., Leutbecher, T. ve Frönlich, S., Ultrahigh performance concrete, UHPC: Fundamentals, design, examples, BetonKalender, Wilhelm Ernst \& Sohn, Berlin, Germany, (2014).

[23] Hussein, L. ve Amleh, L., Size effect of ultra-high performance fiber reinforced concrete composite beams in shear, Structural Concrete, 19, 1, 141-151, (2018).

[24] ACI PRC-239-18, Ultra-high-performance concrete: An emerging technology report, American Concrete Institute, Farmington Hills, MI, USA, (2018).

[25] Song, H-W. ve Saraswathy, V., Studies on corrosion resistance of reinforced steel in concrete with ground granulated blast-furnace slag - An overview, Journal of Hazardous Materials, 138, 2, 226-233, (2006).

[26] Yazıcı, H., Yiğiter, H., Karabulut, A.Ş. ve Baradan, B., Utilization of fly ash and ground granulated blast furnace slag as an alternative silica source in reactive powder concrete, Fuel, 87, 12, 2401-2407, (2008).

[27] Yazıcı, H., Yardımc1, M.Y., Aydın, S. ve Karabulut, A.Ş., Mechanical properties of reactive powder concrete containing mineral admixtures under different curing regimes, Construction and Building Materials, 23, 3, 1223-1231, (2009).

[28] Vaitkevicius, V., Serelis, E. ve Hilbig, H., The effect of glass powder on the microstructure of ultra high performance concrete, Construction and Building Materials, 68, 102-109, (2014).

[29] Soliman, N.A. ve Tagnit-Hamou, A., Development of ultra high performance concrete using glass powder-towards ecofriendly concrete, Construction and Building Materials, 125, 600-612, (2016).

[30] Soliman, N.A. ve Tagnit-Hamou, A., Partial substitution of silica fume with fine glass powder in UHPC: Filling the micro gap, Construction and Building Materials, 139, 374-383, (2017).

[31] Yalçınkaya, Ç. ve Yazıcı, H., Effects of ambient temperature and relative humidity on early-age shrinkage of UHPC with high-volume mineral admixtures, Construction and Building Materials, 144, 252-259, (2017).

[32] Shaikh, F.U.A., Nishiwaki, T. ve Kwon, S., Effect of fly ash on tensile properties of ultra high performance fiber reinforced cementitious composites (UHP-FRCC), Journal of Sustainable Cement-Based Materials, 7, 3, 1-15, (2018).

[33] Du, H. ve Tan, K.H., Properties of high volume glass powder concrete, Cement and Concrete Composites, 75, 22-29, (2017).

[34] Ceylan, S., Yazıcıŏlu, S. ve Turanlı, L., Usage of micronized zeolite in high performanced concrete, Journal of the Faculty of Engineering and Architecture of Gazi University, 36, 1, 163-176, (2021).

[35] Yazıcı, H., Yardımcı, M.Y., Yiğiter, H., Aydın, S. ve Türkel, S., Mechanical properties of reactive powder concrete containing high volumes of ground 
granulated blast furnace slag, Cement and Concrete Composites, 32, 8, 639648, (2010).

[36] Yazıc1, H., The effect of curing conditions on compressive strength of ultra high strength concrete with high volume mineral admixtures, Building and Environment, 42, 5, 2083-2089, (2007).

[37] Wu, Z., Shi, C., He, W. ve Wu, L., Effects of steel fiber content and shape on mechanical properties of ultra high performance concrete, Construction and Building Materials, 103, 8-14, (2016).

[38] Birol, T., Hasgul, U., Terzi, M., Yavaş, A., Turker, K. ve Yazıcı, H., Effect of different steel fiber type and content in flexural behavior of ultra high performance fiber reinforced concrete, Proceedings, 3rd International Balkans Conference on Challenges of Civil Engineering, 262-272, Tirana, Albania, (2016).

[39] Arel, H.Ş., Effects of curing type, silica fume fineness, and fiber length on the mechanical properties and impact resistance of UHPFRC, Results in Physics, 6, 664-674, (2016).

[40] Smarzewski, P., Effect of curing period on properties of steel and polypropylene fibre reinforced ultra-high performance concrete, IOP Conference Series: Materials Science and Engineering, 245, 3, 032059, (2017).

[41] Bıçakçıoğlu, N., Cam tozu ve yüksek firın cürufu kullanımlarının ultra yüksek performanslı beton karışımlarının basınç dayanımına etkisi, Yüksek Lisans Tezi, Balıkesir Üniversitesi, Fen Bilimleri Enstitüsü, Balıkesir, (2020).

[42] BS EN 12390-3:2009, Testing hardened concrete - Part 3: Compressive strength of test specimens, British Standards Institution, Milton Keynes, UK, (2009).

[43] Yoo, D.Y. ve Yoon, Y.S., Structural performance of ultra-high- performance concrete beams with different steel fibers, Engineering Structures, 102, 409423, (2015).

[44] Kou, S.C. ve Xing, F., The effect of recycled glass powder and reject fly ash on the mechanical properties of fibre-reinforced ultrahigh performance concrete, Advances in Materials Science and Engineering, 263243, 1-8, (2012). 